\title{
Research on Innovative Computing of Community Governance Capacity in Xiacheng District of Hangzhou
}

\author{
Li Qiang1,a, Liu Kejin ${ }^{2, b}$ \\ ${ }^{1}$ School of Art and Media, Beijing Normal University, Beijing, China \\ ${ }^{2}$ School of Business, Beijing Institute of Fashion Technology, Beijing, China
}

\begin{abstract}
Deepening the reform of the cultural system and promoting the all-round prosperity of cultural undertakings and the rapid development of the cultural industry are vital to the realization of the goal of building a moderately prosperous society in an all-round way, to the overall layout of the cause of socialism with Chinese characteristics, and to the great rejuvenation of the Chinese nation. Public cultural services refer to the public cultural facilities, cultural products, cultural activities and other related services provided by the government with the participation of social forces for the main purpose of meeting the basic cultural needs of citizens. Hangzhou Xiacheng District is the first community public cultural service performance evaluation mechanism in China, which provides a sample for modern public cultural services in urban communities across the country, and also provides exemplary experience for promoting the modernization of community governance system and governance capacity. This study uses innovative evaluation methods to make an empirical analysis of community governance capacity in Xiacheng District of Hangzhou, and tries to find the reasonable calculation method
\end{abstract}

\section{INTRODUCTION}

In 2014, Xicheng District of Hangzhou initiated the performance evaluation mechanism of community public cultural service in China, and explored the construction of a new model of community public cultural service that people are satisfied with. This mode promoted the overall improvement of the public cultural service level and realized the leapfrog development from the 68th place to the 4th place in the public cultural performance ranking of the province. Dynamic evaluation refers to the Hangzhou downtown community public cultural services through the cultural management, investment, cultural facilities, cultural team, cultural services, service quality, innovation indicators such as data acquisition, parameter gathering and weighted calculation, in order to dynamic and truly reflect each work of the evaluation of the present situation of public cultural services in the community. This promotion provides samples for reference for modern public cultural services in urban communities across the country, and also provides demonstration experience for promoting the modernization of community governance system and governance capacity.

\section{Classification of Evaluation INDICATORS}

\subsection{Content of Evaluation Indicators}

Based on index content, index system of the whole can be divided into "cultural management, investment, cultural facilities, cultural team, cultural services, quality of service and innovation" seven first-level indicators, "the organization construction, cultural security and community input and comprehensive service center of culture, community culture administrator, number of activities of the people, public cultural service satisfaction", such as 30 secondary indexes. See Figure 1 for the distribution diagram of specific indicators. 


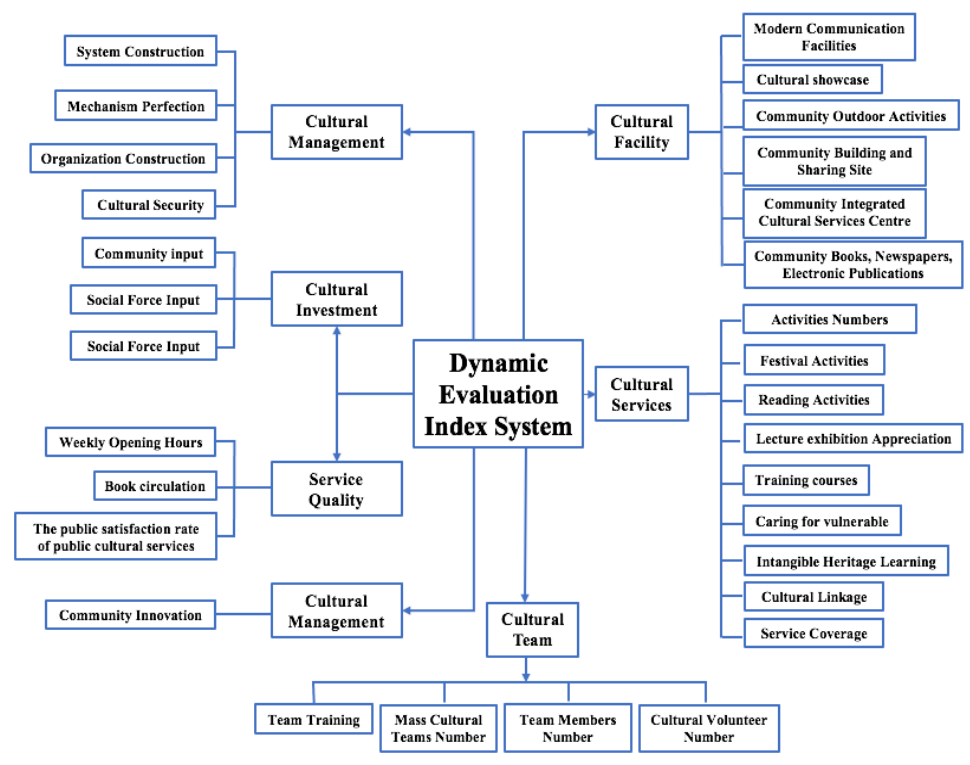

Fig. 1 Community Public Cultural Service Performance Evaluation Index Content Composition Chart

\subsection{Category of Evaluation Indicators}

According to the evaluation method, the whole index system can be divided into three categories: work completion (8 items), ranking calculation (18 items), hierarchical ranking calculation (4 items), and another innovation indicator.

- Job completion indicators mainly consider the target completion of community-related indicators, which require the community to provide ledgers or proof materials. They are scored uniformly by means of assessment and evaluation, without ranking.

- Ranking calculation indicators mainly ranks the values of the indicators related to community public cultural services. According to the ranking results, the corresponding weight score is generated. The calculation formula is: [number of communities -(index ranking)+1]/ number of communities * index weight.

- Hierarchical ranking calculation indicators set different bottom lines for each index, and different bottom lines correspond to different index weights. The calculation method is equivalent to ranking evaluation indexes. For example, "area of community comprehensive cultural service center" is divided into more than 300 square meters (index weight of 4 points), 150-299 square meters (index weight of 2 points) and less than 150 square meters (no points). The main purpose is to open up the gap through the setting of the level, so that the community can further clarify the level of the standard of the index.

- Innovation indicators is the bonus points of the index system. The bonus points are based on the honor obtained by the community's innovation and excellence creation work without any bottom line or upper limit.

See Table 1, Table 2 and Table 3 for the distribution diagram of specific indicators.
Table 1 Job Completion Indicators

\begin{tabular}{|c|c|}
\hline Category & Indicators \\
\hline $\begin{array}{c}\text { Cultural } \\
\text { Management }\end{array}$ & $\begin{array}{c}\text { System Construction; Mechanism } \\
\text { Perfection; Organization } \\
\text { Construction; Cultural Security; }\end{array}$ \\
\hline $\begin{array}{c}\text { Cultural } \\
\text { Facilities }\end{array}$ & $\begin{array}{c}\text { Modern Communication Facilities; } \\
\text { Cultural Showcase; }\end{array}$ \\
\hline Cultural Team & Team Training \\
\hline $\begin{array}{c}\text { Service } \\
\text { Quality }\end{array}$ & $\begin{array}{r}\text { The Public Satisfaction Rate of } \\
\text { Public cultural services; }\end{array}$ \\
\hline
\end{tabular}

Table 2 Ranking Calculation Indicators

\begin{tabular}{|c|c|}
\hline Category & Indicators \\
\hline $\begin{array}{c}\text { Cultural } \\
\text { Investment }\end{array}$ & $\begin{array}{c}\text { Community Input; Social Force } \\
\text { Input; Per Capita Expenditure on } \\
\text { Public Cultural Activities; }\end{array}$ \\
\hline $\begin{array}{l}\text { Cultural } \\
\text { Facilities }\end{array}$ & $\begin{array}{c}\text { Community Outdoor Activities; } \\
\text { Community Building and Sharing } \\
\text { Site }\end{array}$ \\
\hline $\begin{array}{l}\text { Cultural } \\
\text { Team }\end{array}$ & $\begin{array}{l}\text { The Number of Mass Cultural } \\
\text { Teams; Number of Team Members; } \\
\text { Cultural Volunteer Service; }\end{array}$ \\
\hline $\begin{array}{l}\text { Cultural } \\
\text { Services }\end{array}$ & $\begin{array}{c}\text { Number of Organizational } \\
\text { Activities; Festival Activities; } \\
\text { Reading Activities; Lecture } \\
\text { Exhibition Appreciation; Training } \\
\text { Courses; Caring for the Vulnerable; } \\
\text { Intangible Heritage Learning; } \\
\text { Cultural Linkage; Service } \\
\text { Coverage; }\end{array}$ \\
\hline $\begin{array}{l}\text { Service } \\
\text { Quality }\end{array}$ & Book circulation; \\
\hline
\end{tabular}


Table 3 Hierarchical ranking calculation indicators

\begin{tabular}{|c|c|}
\hline category & indicators \\
\hline $\begin{array}{c}\text { Cultural } \\
\text { Facilities }\end{array}$ & $\begin{array}{c}\text { Community Integrated Cultural } \\
\text { Services Centre; Community Books, } \\
\text { Newspapers, Electronic } \\
\text { Publications; }\end{array}$ \\
\hline $\begin{array}{c}\text { Cultural } \\
\text { Team }\end{array}$ & Community Cultural Manager \\
\hline $\begin{array}{c}\text { Service } \\
\text { Quality }\end{array}$ & Weekly Opening Hours \\
\hline
\end{tabular}

\section{INDEX WEIGHT}

In the process of setting up the evaluation index system of community public cultural service, Xiacheng District has broken the traditional single evaluation or ranking mode of performance evaluation. At the same time, it increases the proportion of soft indexes such as service supply and service efficiency. See Figure 2 and Figure 3 for the distribution diagram of specific weight ratio.

\section{The Weight Distribution}

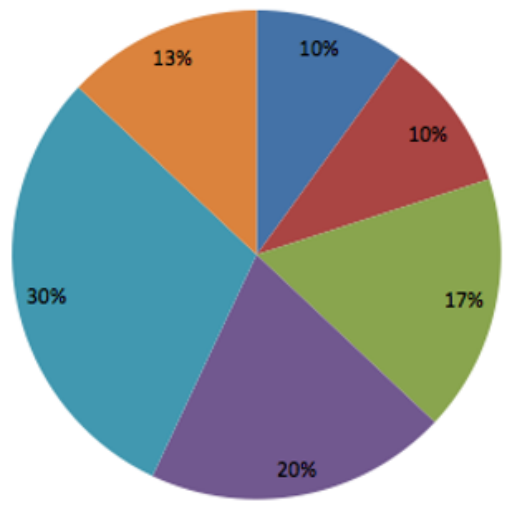

- Cultural Management

- Cultural Investment

n Cultural Facility

- Cultural Team

n Cultural Services

n Services Quality

Fig. 2 Weight score diagram of first-level indicators of community public cultural service evaluation system

\begin{tabular}{|l|l|}
\hline 1 Point & $\begin{array}{l}\text { System Construction \& Cultural Security(Cultural Management) ; Cultural } \\
\text { Showcase(Cultural Facilities); }\end{array}$ \\
\hline 2 Points & $\begin{array}{l}\text { Per Capita Expenditure on Public Cultural Activities (Cultural } \\
\text { Investment) } \\
\text { Community Outdoor Activities \& Community Building and Sharing Site \& } \\
\text { Modern Communication Facilities(Cultural Facilities ; Cultural } \\
\text { Linkage(Cultural Services) }\end{array}$ \\
\hline Points & $\begin{array}{l}\text { System Construction(Cultural Management); Mass Cultural Teams } \\
\text { Number\&Cultural Volunteer Number(Cultural Team); Festival Activities \& } \\
\text { Reading Activities \& Lecture Exhibition Appreciation \& Training Course \& } \\
\text { Caring for the vulnerable \& Intangible Heritage Learning (Cultural Services) }\end{array}$ \\
\hline 5 Points & $\begin{array}{l}\text { Community input \& Social Force Input (Cultural Investment); } \\
\text { Community Integrated Cultural Services Centre (Cultural Facilities) }\end{array}$ \\
\hline 6 Points & Activities Numbers \& Service Coverage(Cultural Services) \\
\hline 7 Points & Community Books, Newspapers, Electronic Publications (Cultural Facilities) \\
\hline 9 Points & The public satisfaction rate of public cultural services(Service Quality) \\
\hline Unlimited & Community Innovation \\
\hline
\end{tabular}

Fig. 3 Weight score diagram of secondary indicators of community public cultural service evaluation system

\section{DATA ACQUISITION AND REVIEW}

Xiacheng district independently developed the dynamic performance management system of community public cultural service, which realized three functions of data reporting, summary analysis and dynamic ranking.

All data filling should go through the process of "community upload -- street preliminary review -- District Bureau review -- return and correction -- review and approval". In the process of audit, the authenticity and objectivity of doubt or incomplete data of relevant certification materials shall not be approved, which guarantees the authenticity and validity of the data of the whole reporting system from the source. The audited data will be used as a trusted source for the final assessment data. 


\section{Calculation method}

\subsection{Job Completion Indicators}

The indicators of work completion mainly reflect the completion of work. The method is to provide relevant standing books or testimonial materials, and to conduct unified scoring by means of assessment and evaluation, without ranking.

\subsection{Rankings Calculated Indicators}

- $\quad$ The formula to calculate Score of this indicator $=[$ Number of communities - (ranking ) +1]/ Number of communities * Index weight

- Example: "Community engagement" indicator The "community input" of a certain community ranks 35th among the 74 communities in the region, and the weight of this index is 4 points. Therefore, the score of this community's "community input" index is: $[74-35+1] / 74 * 4=2.16$.

\subsection{Hierarchical Ranking Calculation Indicators}

- The calculation of the weight of such indicators is divided into several levels. First, according to the value of the community, the statisticians find the index weight corresponding to the value. And then get the score according to the ranking and using the calculation formula.

Score of this indicator $=[$ Number of communities - (ranking ) +1]/ Number of communities * Index weight

- Example: hierarchical ranking calculation indicators

a) A community cultural service center with an indoor total area of 1,000 square meters ranks 10th among 74 communities in the region. the score of the index of "Community comprehensive cultural Service Center" in this community is: $[74-10+1] / 74 * 4=3.51$;

b) The total indoor area of a community cultural service center is 284 square meters, ranking the 56th in the whole region. The index weight of the value with an area of 150-299 square meters is 2 points, so the score of the index of "Community Comprehensive Cultural Service Center" in this community is: $[74-56+1] / 74 * 2=0.51$;

c) The total indoor area of a community cultural service center is 130 square meters, ranking the 70th in the whole region. But the index is less than 150 square meters, so although there is a ranking, there is no score.

\subsection{Indicatorsinnovation indicators}

The scoring items and criteria of innovation indicators are as follows:
The original program gets 8 points for the honor of the Ministry of Culture or the provincial government, 6 points for the honor of the Provincial Department of Culture or the municipal government, 4 points for the honor of the Municipal Bureau of Culture and Broadcasting or the district Government, and 2 points for the honor of the District Bureau of Culture and Broadcasting.

\section{Evaluation RESULts}

Evaluations are generally conducted once a year. A comprehensive dynamic assessment of the indicators of the previous year is conducted at the beginning of each year. Through scientific process management and rigorous data control, the performance evaluation system of community public cultural service is ensured to operate reasonably and effectively, and the final evaluation results can truly reflect the current situation and problems of community public cultural service. The evaluation results can be applied to the allocation of public cultural resources in each neighborhood and community, the formulation of public cultural service development policies, and the periodic statistical analysis of regional public cultural service data, etc., which are the important decision-making basis for the construction of modern public cultural service system in lower urban areas.

\section{REFERENCES}

1. C.Hood.A Public Management for all Seasons?[J].Public Administration , 1991 , 69 (Spring) , p3-19.

2. Paul C Light.The Tides of Reform : Making Government Work 1945-1995[J].Yale University Press, 1997.

3. B.Guy Peters.The Future of Governing : Four Emerging Models[J].University Press of Kansas, 1996, p28.

4. Charles Fox.Reinventing Government As Postmodern Symbolic Politics[J]. Public Administration Review, 1996, 56 (03) , p256-261.

5. Larry D.Terry.Why We Should Abandon the Misconceived Quest to Reconcile Public Entrepreneurship with Democracy[J].Public Administration Review， 1993， 53 (04) ， p393-395.

6. WORLD BANK.Governance and Development[R]. Washington : World Bank, 1992, (08).

7. Williamson, O.E. On the Governance of the Modern Corporation[J].Hofstra Law Review, 8(Fall):63-78.

8. Williamson, O.E. Corporate Governance[J].Yale Law Journal, 93(June) ; 1984.

9. The Economics of Governance : Framework and Implications[J].Journal of Theoretical Economics, 140(March) : 195-223 ; 1985.

10. Blair, M.M. Ownership and Control : Rethinking Corporate Governance for the Twenty-first 
Century.The Brookings Institution, Washington, D.C., 1995.

11. Young, D. R. The First Three Years of NML : Central Issues in the Management of Nonprofit Organizations[J].Nonprofit Management \& Leadership, 1993, 4(1), p3-22.

12. Richard J Umbdenstock, CHE, President-elect and Chief Operating Officer , American Hospital Association[J].Washington, D.C.in his Practitioner Application 2000(06).

13. Houle.C.O.Governing Boards : Their Nature and Nurture[J].San Francisco:Jossey Bass Publishers, 1997.
14. Blair, M.M., 1995, Ownership and Control : Rethinking Corporate Governance for the Twentyfirst Century, The Brookings Institution , Washington, D.C., 1995.

15. Jensen, M.andW.Meckling.Theory of the Firm : Managerial Behavior, Agency Costs and Ownership Structure[J].Journal of Financial Economics , 3(October) : 305-60.

16. Jensen M.andR.Ruback.The Market for Corporate Control : the Scientific Evidence[J].Journal of Financial Economics, 11 : 5-50. 